\title{
The value of endobronchial cryotherapy in the management of malignant endobronchial obstruction in patients with inoperable NSCLC: a prospective analysis of clinical and survival outcomes
}

\author{
Alaa Rashad ${ }^{1}$, Mohamed Shahat Badawy ${ }^{2}$, Mohammed Mustafa Ali ${ }^{3}$, Haggagy Mansour ${ }^{1}$ and \\ Mohamed Abdel-Bary ${ }^{4^{*}}$ (D)
}

\begin{abstract}
Background: Malignant endobronchial obstruction (MEBO) is the most debilitating complication in non-small cell lung cancer (NSCLC). The therapeutic role of cryotherapy and its impact on survival has not been well addressed. This is to clarify whether the combination of endobronchial cryotherapy (EBCT) and chemoradiotherapy (CRT) improved symptoms, respiratory functions, performance status, and survival outcomes in inoperable NSCLC with symptomatic MEBO compared to that obtained by CRT alone.
\end{abstract}

Results: A prospective cohort study included 60 cases presented to Qena University Hospital, Egypt, between December 2016 and May 2019. They were divided into two groups. Group A included 30 patients who were managed with EBCT plus CRT. Group B included 30 patients who were managed with CRT alone. The outcomes assessed were symptoms relief, respiratory function tests (RFT), performance status, and survival outcomes at baseline and 4 weeks of follow-up. Group A patients showed a highly significant improvement in symptoms (cough, dyspnea, and hemoptysis), RFT, 6MWD test, and arterial blood gases, compared to group B. The mean Karnofsky score increased from $57.33 \pm 5.67 \%$ at baseline to $60.67 \pm 6.39 \%$ post-EBCT $(P=0.036)$; group A was significantly improved compared to group $B(P=0.04)$. The Kaplan-Meier median survival for all patients was $9.7 \pm 0.4$ months $(95 \% \mathrm{Cl}=8.86-10.54)$, and group $A$ cases $(10.77 \pm 0.44$ months, $95 \% \mathrm{Cl}=9.9-11.6)$ was significantly longer than that of group B cases ( $8.6 \pm 0.68$ months, $95 \% \mathrm{Cl}=7.3-9.97 ; T$ test $=2.631, P=0.011)$.

Conclusion: The use of EBCT with CRT for the management of MEBO in symptomatic patients with inoperable NSCLC is an efficient and safe procedure. EBCT improves clinical outcomes, RFT, performance status, and median survival.

Trial registration: ClinTrial.Gov registration: NCT04710459 on 4/3/2021.

Keyword: Non-small-cell lung carcinoma, Cryotherapy, Malignant endobronchial obstruction, Median survival

\footnotetext{
* Correspondence: Dr_abdelbary@med.svu.edu.eg

${ }^{4}$ Department of Cardiothoracic Surgery, Qena Faculty of Medicine, South

Valley University, Qena, Egypt

Full list of author information is available at the end of the article
}

\section{Springer Open}

(c) The Author(s). 2021 Open Access This article is licensed under a Creative Commons Attribution 4.0 International License, which permits use, sharing, adaptation, distribution and reproduction in any medium or format, as long as you give appropriate credit to the original author(s) and the source, provide a link to the Creative Commons licence, and indicate if changes were made. The images or other third party material in this article are included in the article's Creative Commons licence, unless indicated otherwise in a credit line to the material. If material is not included in the article's Creative Commons licence and your intended use is not permitted by statutory regulation or exceeds the permitted use, you will need to obtain permission directly from the copyright holder. To view a copy of this licence, visit http://creativecommons.org/licenses/by/4.0/. 


\section{Background}

Globally, bronchogenic carcinoma is the leading cause of cancer-related mortality worldwide [1]. Non-small cell lung cancer (NSCLC) accounts for $85 \%$ of all lung cancers [2]. Malignant endobronchial obstruction (MEBO) refers to any malignant, mechanical, obstructive process that impedes the airflow within the central airways (trachea, main-stem bronchi, and right bronchus intermedius), and it complicates one third of these cases. This may occur via bronchial edema, invasion, or endoluminal growth. In advanced bronchogenic carcinoma with malignant obstruction, airway compromise occurs as cancer continues to progress [3, 4]. This will lead to atelectasis, pneumonia, and decrease response to chemoradiotherapy (CRT). Also, it affects patients' survival and responsible for $40 \%$ mortality. Moreover, inoperable NSCLC cases without MEBO have better survival than those with MEBO $[5,6]$. Recently, due to the difficulty of NSCLC management, it is recommended to utilize a multidisciplinary team, including chest physicians, surgeons, oncologists, and interventional radiologists, to provide optimal, multimodality therapy options for these patients [7, 8].

Many interventional procedures have been evolved for MEBO ablation to relieve bronchial obstruction and alleviate symptoms. The basis of these procedures includes endobronchial tumor debulking, tumerectomy (laser, electrocautery, argon plasma coagulation, and cryotherapy), stents insertion, photodynamic therapy, or chemotherapy injection. The rationale for each procedure choice depends on tumor characteristics, degree of obstruction, patient clinical presentation, practitioner expertise, and equipment availability $[9,10]$.

The principle of endobronchial cryotherapy (EBCT) is the local tumor cell apoptosis and destruction by extreme cold application to tissues. EBCT is a cheap, safe, and reproducible method for $\mathrm{MEBO}$ palliation in patients with inoperable bronchogenic carcinoma; its therapeutic role and its impact on survival outcomes have not been well addressed, and a few studies about the impact of post-EBCT on performance status [11, 12]. Therefore, our study aimed to clarify whether the combination of EBCT and CRT improved the clinical outcomes, respiratory functions, performance status, and survival outcomes compared to those obtained by CRT alone in patients with inoperable NSCLC with symptomatic MEBO.

\section{Methods}

\section{Study design}

This is a single-center, random, prospective cohort study that included 60 inoperable NSCLC cases presented with symptomatic MEBO, between December 2016 and May 2019. The study conformed to the ethical standards of the Helsinki Declaration, and approval was obtained from the IRB. Signed consent was taken from all cases. The outcomes assessed were symptoms relief, performance status, and survival outcomes.

\section{Subjects}

The study cases were randomly divided into two groups. Group A included 30 patients who were managed with EBCT plus CRT. However, group B included include 30 patients who were managed with CRT alone. The cases were considered inoperable for the following reasons: advanced unresectable bronchogenic carcinoma (stages III and IV), multiple metastases, advanced age, or refusal of surgery. All cases were evaluated clinically, radiologically, and for performance status at baseline before the procedure and 4 weeks after the procedure. All cases with pathologically proven, inoperable NSCLC cases with symptomatic MEBO obstructing $>50 \%$ of the airways lumen in the proximal main bronchi or intermediate bronchus were included in the study. Cases with severe respiratory distress, uncorrectable impaired coagulation profile, and without $\mathrm{MEBO}$ were excluded from the study. All patients had CT chest and chest Xray performed in their initial evaluation and 4 weeks post-procedure. All patients underwent clinical evaluation for dyspnea, hemoptysis, cough, and chest pain. The Medical Research Council (MRC) scale was used for clinical dyspnea evaluation.Six-minute walking distance (6MWD) test and spirometry for the assessment of forced expiratory volume 1 (FEV1) and forced vital capacity (FVC) were done at baseline before the procedure and 4 weeks after the procedure. The performance status was assessed using the Karnofsky score.

\section{Methods \\ Chemoradiotherapy}

It was $5000 \mathrm{CGY}$ in conventional fractionation on the lung mass only, along with a concurrent gemcitabine short infusion of $600 \mathrm{mg}$ per square meter weekly.

\section{Endobronchial cryotherapy}

A cryoprobe (Erbe, Germany, Flexible, $80 \mathrm{~cm}, 2.2 \mathrm{~mm}$ in diameter) with nitrous oxide as a cryogen was used. The procedure was done via flexible bronchoscopy (PENT AX EB-1970K, $2.8 \mathrm{~mm}$ channel) under intravenous midazolam sedation and local anesthesia with $2 \%$ xylocaine solution or gel. Routine monitoring was done for all cases during bronchoscopy [13]. The patient lay comfortably in a semirecumbent position. The bronchoscope was introduced transnasally into the tracheal and bronchial lumen. The distal end of the bronchoscope is placed approximately $5 \mathrm{~mm}$ above the proximal end of the lesion, and the appropriate cryoprobe is inserted 
through the biopsy channel of the bronchoscope and applied to the tumor.

EBCT was started with $-80^{\circ} \mathrm{C}$ at the probe tip from 20 to $60 \mathrm{~s}$ at the lesion site and then allowed to thaw until the probe separated from the tissue. The probe was then moved 5-6 $\mathrm{mm}$ and another one to three freeze-thaw cycles carried out in the adjoining area. The procedure was continued until the entire visible part of the tumor had been frozen. Necrotic tumor material was removed after each cryo-application using a biopsy-type clamp. After complete removal of the mass, the bronchoscope was reintroduced to check for airway patency. The procedure was considered successful if airway patency of at least $80 \%$ of the normal was achieved post-EBCT. The procedure took approximately $20 \mathrm{~min}$, and most patients recovered well enough to be discharged on the same day.

\section{Statistical analysis}

The Statistical Package for Social Sciences (IBM-SPSS), version 25 (IBM-Corporation, Chicago, USA; August 2017) was used for statistical data analysis. Data are expressed as mean, standard deviation (SD), number, and percentage. Student $t$ test was used to compare the means between two groups, and the Pearson chi-square test was used to compare percentages of qualitative variables. The paired $t$ test was used to compare means of the same variable at different periods, and the McNemar chi-square test was used to compare percentages of the same variables at different periods also. Survival outcomes were assessed using the Kaplan-Meier curve analysis. For all these tests, the level of significance $(P$ value) was explained as non-significant $P>0.05$, significant $P<0.05$, and highly significant $P<0.001$.

\section{Results}

\section{Baseline clinical data}

Group A included 30 patients; their mean age was $56.73 \pm 8.5$ years and $18(60 \%)$ patients were males. Group B included 30 patients with a mean age of 59.4 \pm
12 years and 14 (47\%) patients were males (Table 1). Both groups were comparable regarding the baseline clinical data (cough, dyspnea, hemoptysis, and chest pain). The most distressing complaint was hemoptysis, which was present in all cases $(100 \%)$ in group A and group B in 28 (93\%) cases. Also, dyspnea was presented in $26(87 \%)$ cases in group A and $28(93 \%)$ cases in group B. In each group, $24(80 \%)$ cases presented with cough.

Respiratory function tests (RFT) showed obstructive values in both groups, and they were comparable regarding the baseline RFT $(P=0.6)$. The 6MWD and arterial blood gases $(\mathrm{ABG})$ were comparable $(P>0.05)$. Also, both groups were comparable regarding the performance status $(P=0.8)$ (Table 2).

Group A patients were subdivided into two subgroups, 21 patients with main bronchial obstruction (group A1) and 9 patients with lobar obstruction (group A2). They were comparable regarding the baseline clinical data, baseline RFT, 6MWD, ABG, and performance status (Table 3).

\section{Post procedures clinical outcomes}

EBCT was performed successfully in all group A cases. Also, it resulted in a highly significant improvement in hemoptysis, dyspnea, and cough $(P<0.001)$ and a nonsignificant improvement in chest pain $(P=0.09)$ at 4 weeks follow-up. However, group B cases showed a nonsignificant improvement in hemoptysis, cough, dyspnea, or chest pain $(P>0.05)$ at 4 weeks follow-up.

Meanwhile, group A patients showed a highly significant improvement in cough, dyspnea, and hemoptysis than group $B(P<0.001)$. There was a nonsignificant improvement in chest pain among both groups $(P=0.5)$. There was no mortality, bleeding, or any other life-threatening complications in group A. Also, none of group B patients experienced severe side effects (Table 2).

In group A1, there was a highly significant improvement in hemoptysis, dyspnea, and cough $(P<0.001)$ and

Table 1 Preoperative demographic data

\begin{tabular}{|c|c|c|c|c|}
\hline Variable & & Group A $(n=30)$ & Group B $(n=30)$ & $P$ value \\
\hline Age & & $56.73 \pm 8.5$ & $59.4 \pm 12$ & 0.5 \\
\hline Gender (male) & & $18(60 \%)$ & $14(46.7 \%)$ & 0.5 \\
\hline \multirow[t]{3}{*}{ Comorbidities } & Hypertension & $21(70 \%)$ & 19 (63.3\%) & 0.6 \\
\hline & Diabetes mellitus & 7 (23.3\%) & $8(26.7 \%)$ & \\
\hline & COPD & $9(30 \%)$ & $6(20 \%)$ & \\
\hline \multirow[t]{4}{*}{ Special habits } & Current smoker & $8(27 \%)$ & 10(33\%) & \\
\hline & Ex-smoker & 10 (33\%) & 10 (33\%) & \\
\hline & Bird breader & $8(27 \%)$ & $8(27 \%)$ & \\
\hline & No special habits & $4(13 \%)$ & $2(7 \%)$ & \\
\hline
\end{tabular}


Table 2 Comparison of the clinical presentation outcomes, respiratory function tests, arterial blood gases, and the mean Karnofsky performance score for group A (EBCT+CRT) and group B (CRT) at baseline and follow-up after the procedure

\begin{tabular}{|c|c|c|c|c|c|c|c|c|c|}
\hline \multicolumn{2}{|l|}{ Variable } & \multicolumn{2}{|l|}{ Group A } & \multicolumn{2}{|l|}{ Group B } & \multirow{2}{*}{$\begin{array}{l}P \text { values } \\
\text { I \& II }\end{array}$} & \multirow{2}{*}{$\begin{array}{l}P \\
\text { values } \\
\text { I \& III }\end{array}$} & \multirow{2}{*}{$\begin{array}{l}P \text { values } \\
\text { II \& IV }\end{array}$} & \multirow{2}{*}{$\begin{array}{l}P \text { values } \\
\text { III \& IV }\end{array}$} \\
\hline & & $\begin{array}{l}\text { Pre- } \\
\text { cryotherapy } \\
(\mathrm{I}) \\
(n=30)\end{array}$ & $\begin{array}{l}\text { Post- } \\
\text { cryotherapy } \\
\text { (II) } \\
(n=30)\end{array}$ & $\begin{array}{l}\text { Pre- } \\
\text { therapy } \\
\text { (III) } \\
(n=30)\end{array}$ & $\begin{array}{l}\text { Post } \\
\text { therapy } \\
\text { (IV) } \\
(n=30)\end{array}$ & & & & \\
\hline \multirow[t]{4}{*}{ Clinical presentation } & Cough & $24(80 \%)$ & $6(20 \%)$ & $24(80 \%)$ & $22(73 \%)$ & $<0.001$ & 1.000 & $<0.001$ & 0.592 \\
\hline & Dyspnea & $26(87 \%)$ & $6(20 \%)$ & $28(93 \%)$ & $24(80 \%)$ & $<0.001$ & 0.667 & $<0.001$ & 0.254 \\
\hline & Hemoptysis & $30(100 \%)$ & 0 & $28(93 \%)$ & $26(87 \%)$ & $<0.001$ & 0.472 & $<0.001$ & 0.667 \\
\hline & Chest pain & $12(40 \%)$ & $6(20 \%)$ & $10(32 \%)$ & $8(27 \%)$ & 0.090 & 0.592 & 0.541 & 0.573 \\
\hline \multirow{3}{*}{$\begin{array}{l}\text { Respiratory function } \\
\text { tests }\end{array}$} & Mean FVC \% & $62.13 \pm 2.8$ & $65 \pm 3.65$ & $62.47 \pm 1.8$ & $62.53 \pm 1.7$ & 0.001 & 0.578 & 0.001 & 0.895 \\
\hline & Mean FEV1 \% & $64.53 \pm 3.8$ & $69.87 \pm 4.0$ & $65 \pm 2.9$ & $65 \pm 2.6$ & $<0.001$ & 0.592 & $<0.001$ & 1.000 \\
\hline & $\begin{array}{l}\text { Mean 6MWT } \\
(\mathrm{m})\end{array}$ & $262 \pm 56$ & $330 \pm 76$ & $287 \pm 78$ & $292 \pm 48$ & $<0.001$ & 0.159 & 0.024 & 0.766 \\
\hline \multirow[t]{4}{*}{ Arterial blood gases } & Mean PH & $7.382 \pm .02$ & $7.385 \pm .01$ & $7.381 \pm .01$ & $7.39 \pm 0.03$ & 0.465 & 0.807 & 0.390 & 0.124 \\
\hline & Mean So2 & $87.07 \pm 1.8$ & $90.4 \pm 1.5$ & $86.7 \pm 1.9$ & $87 \pm 1.7$ & $<0.001$ & 0.442 & $<0.001$ & 0.522 \\
\hline & Mean $\mathrm{PaO} 2$ & $77.07 \pm 1.8$ & $82.9 \pm 1.8$ & $76.9 \pm 2.4$ & $77.3 \pm 2.6$ & $<0.001$ & 0.757 & $<0.001$ & 0.538 \\
\hline & Mean $\mathrm{PaCo} 2$ & $36.9 \pm 1.6$ & $41 \pm 1.1$ & $37.7 \pm 1.8$ & $38.2 \pm 1.9$ & $<0.001$ & 0.074 & $<0.001$ & 0.300 \\
\hline \multicolumn{2}{|c|}{ Mean Karnofsky performance score \% } & $57.33 \pm 5.67$ & $60.67 \pm 6.39$ & $56.87 \pm 9.19$ & $56.32 \pm 9.63$ & 0.036 & 0.816 & 0.044 & 0.822 \\
\hline
\end{tabular}

a non-significant improvement in chest pain $(P=0.079)$ at 4 weeks follow-up. However, in group A2 cases, there was a non-significant improvement in cough, dyspnea, or chest pain $(P=0.5)$, and there was a highy significant improvement in hemoptysis $(P<0.001)$. Group A1 cases compared to group A2 cases showed a significant improvement in cough and dyspnea $(P<0.028$ and $0.001)$. Hemoptysis improved in both subgroups $(P=1)$ (Table 3).

\section{Impact on RFT, 6MWD test, and ABG}

The EBCT modality proved to be an efficient procedure during this study in achieving a highly significant improvement in the mean FVC and mean FEV1; they were $62.13 \pm 2.8 \%$ and $64.53 \pm 3.8 \%$ pre-EBCT and increased to $65 \pm 3.65 \%$ and $69.87 \pm 4.0 \%$ post-EBCT, respectively $(P<$ $0.001)$. Moreover, this resulted in a highly significant improvement in the mean 6MWD test in group A, which increased from $262 \pm 56 \mathrm{~m}$ at baseline to $330 \pm 76 \mathrm{~m}$ after the 4 weeks follow-up $(P<0.001)$. On the contrary, group $B$ showed a non-significant improvement in the mean FVC, FEV1, or 6MWD test post-therapy $(P>0.05)$. However, group A post-EBCT showed a highly significant improvement in the mean FVC and FEV1 $(P<0.001)$ and a significant improvement in the mean 6 MWD test $(P<$ $0.02)$ in comparison to group B post therapy at 4 weeks follow-up.

Regarding $\mathrm{ABG}$, there was a highly significant improvement in the mean $\mathrm{ABG}$ parameters $\left(\mathrm{SaO}_{2}, \mathrm{PaO}_{2}\right.$, and $\left.\mathrm{PaCO}_{2}\right)$ in group A cases post-EBCT $(P<0.001)$. On the other hand, group $B$ cases showed a non-significant improvement in the mean ABG parameters post-therapy $(P>0.05)$. However, group A cases post-EBCT showed a highly significant improvement in the mean ABG parameters in comparison to group $B$ post therapy at 4 weeks follow-up $(P<0.001)$ (Table 2$)$.

Regarding group A subgroups, group A1 post-EBCT showed a significant improvement in the mean FVC and FEV1 compared to group A2 ( $P=0.049$ and 0.015). However, 6MWD showed a non-significant improvement among both subgroups. There was a highly significant improvement in the mean ABG parameters $\left(\mathrm{SaO}_{2}\right.$, $\mathrm{PaO}_{2}$, and $\mathrm{PaCO}_{2}$ ) in group A1 cases compared to group A2 post-EBCT $(P<0.001)$ (Table 3$)$.

\section{Impact on performance status and median survival}

There was a significant improvement in the mean Karnofsky performance score in group A $(P=0.036)$, and it increased from $57.33 \pm 5.67 \%$ at baseline to $60.67 \pm 6.39 \%$ after 4 weeks of follow-up. On the contrary, group B cases showed a non-significant improvement in the performance status during follow-up in comparison to the pre-CRT value $(P=0.8)$. However, group A showed a significant improvement in performance status in comparison to group B at 4 weeks follow-up $(P=0.04)$ (Table 2$)$.

Regarding group A subgroups, there was a significant improvement in the mean Karnofsky performance score

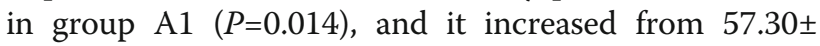
$5.52 \%$ at baseline to $62.04 \pm 6.46 \%$ after 4 weeks of follow-up. However, there was a non-significant improvement in the mean Karnofsky performance score among both group A1 and A2 ( $P=0.177)$ (Table 3$)$. 
Table 3 Comparison of the clinical presentation outcomes, respiratory function tests, arterial blood gases, and the mean Karnofsky performance score for group A subgroups (main bronchi and lobar bronchi obstruction)

\begin{tabular}{|c|c|c|c|c|c|c|c|c|c|}
\hline \multicolumn{2}{|l|}{ Variable } & \multicolumn{2}{|l|}{$\begin{array}{l}\text { Main bronchi } \\
\text { (Group A1) }\end{array}$} & \multicolumn{2}{|c|}{$\begin{array}{l}\text { Lobar bronchi } \\
\text { (Group A2) }\end{array}$} & \multirow[t]{2}{*}{$\begin{array}{l}P \text { values } \\
\text { I \& II }\end{array}$} & \multirow[t]{2}{*}{$\begin{array}{l}P \text { values } \\
\text { I \& III }\end{array}$} & \multirow[t]{2}{*}{$\begin{array}{l}P \text { values } \\
\text { II \& IV }\end{array}$} & \multirow[t]{2}{*}{$\begin{array}{l}P \text { valued } \\
\text { III \& IV }\end{array}$} \\
\hline & & $\begin{array}{l}\text { Pre-cryotherapy } \\
(\mathrm{I}) \\
(n=21)\end{array}$ & $\begin{array}{l}\text { Post-cryotherapy } \\
\text { (II) } \\
(n=21)\end{array}$ & $\begin{array}{l}\text { Pre-therapy } \\
\text { (III) } \\
(n=9)\end{array}$ & $\begin{array}{l}\text { Post therapy } \\
\text { (IV) } \\
(n=9)\end{array}$ & & & & \\
\hline \multirow[t]{4}{*}{ Clinical presentation } & Cough & 18(85.7\%) & $2(9.5 \%)$ & $6(66.7 \%)$ & $4(44.4 \%)$ & $<0.001$ & 0.232 & 0.028 & 0.343 \\
\hline & Dyspnea & $20(95.2 \%)$ & $1(4.8 \%)$ & $6(66.7 \%)$ & $5(55.6 \%)$ & $<0.001$ & 0.128 & 0.001 & 0.629 \\
\hline & Hemoptysis & $21(100 \%)$ & 0 & $9(100 \%)$ & 0 & $<0.001$ & 1.000 & 1.000 & $<0.001$ \\
\hline & Chest pain & $8(38.1 \%)$ & $3(14.3 \%)$ & $4(44.4 \%)$ & 3(33.3\%) & 0.079 & 0.745 & 0.232 & 0.629 \\
\hline \multirow{3}{*}{$\begin{array}{l}\text { Respiratory function } \\
\text { tests }\end{array}$} & Mean FVC \% & $62.21 \pm 1.9$ & $66.81 \pm 2.8$ & $62.11 \pm 2.2$ & $64.2 \pm 3.34$ & $<0.001$ & 0.906 & 0.049 & 0.137 \\
\hline & Mean FEV1 \% & $64.33 \pm 3.5$ & $71.11 \pm 3.8$ & $64.69 \pm 3.8$ & $67.34 \pm 3.6$ & $<0.001$ & 0.809 & 0.015 & 0.148 \\
\hline & $\begin{array}{l}\text { Mean } 6 \mathrm{MWT} \\
(\mathrm{m})\end{array}$ & $259 \pm 55$ & $341 \pm 71$ & $268 \pm 62$ & $301 \pm 59$ & $<0.001$ & 0.709 & 0.121 & 0.264 \\
\hline \multirow[t]{4}{*}{ Arterial blood gases } & Mean PH & $7.382 \pm 0.01$ & $7.386 \pm 0.01$ & $7.381 \pm 0.02$ & $7.383 \pm 0.01$ & 0.202 & 0.888 & 0.458 & 0.792 \\
\hline & Mean So2 & $87.11 \pm 1.9$ & $91.1 \pm 1.9$ & $86.99 \pm 1.6$ & $89.1 \pm 1.8$ & $<0.001$ & 0.860 & 0.011 & 0.018 \\
\hline & Mean $\mathrm{PaO} 2$ & $77.12 \pm 1.9$ & $84.2 \pm 2.2$ & $76.97 \pm 2.1$ & $80.4 \pm 1.9$ & $<0.001$ & 0.855 & $<0.001$ & 0.002 \\
\hline & Mean PaCo2 & $37.01 \pm 1.9$ & $42.81 \pm 0.9$ & $37.72 \pm 1.8$ & $38.72 \pm 1.9$ & $<0.001$ & 0.339 & $<0.001$ & 0.269 \\
\hline \multicolumn{2}{|c|}{$\begin{array}{l}\text { Mean Karnofsky performance score } \\
\%\end{array}$} & $57.30 \pm 5.52$ & $62.04 \pm 6.46$ & $57.39 \pm 5.76$ & $58.28 \pm 6.97$ & 0.014 & 0.969 & 0.177 & 0.772 \\
\hline
\end{tabular}

The median survival for all 60 patients by the KaplanMeier method was $9.7 \pm 0.4$ months $(95 \% \mathrm{CI}=8.86-$ 10.54). The median survival of group A patients (10.77 \pm 0.44 months, $95 \% \mathrm{CI}=9.9-11.6)$ was significantly longer than that of group B cases $(8.6 \pm 0.68$ months, $95 \% \mathrm{CI}=$ 7.3-9.97; $T$ test $=2.631, P=0.011)($ Fig.1) .

There was a non-signifcant change in the median survival among group A1 and group A2 (the median survival; $10.77 \pm 0.44$ months (95\% $\mathrm{CI}=9.90-11.63), \quad T$ test $=0.629, P=0.535$.) (Fig.2).

\section{Discussion}

MEBO is the most debilitating complication that may occur in inoperable NSCLC; especially, about $75 \%$ of cases are not amenable for surgery at the time of diagnosis. Also, in association with hemoptysis and dyspnea,

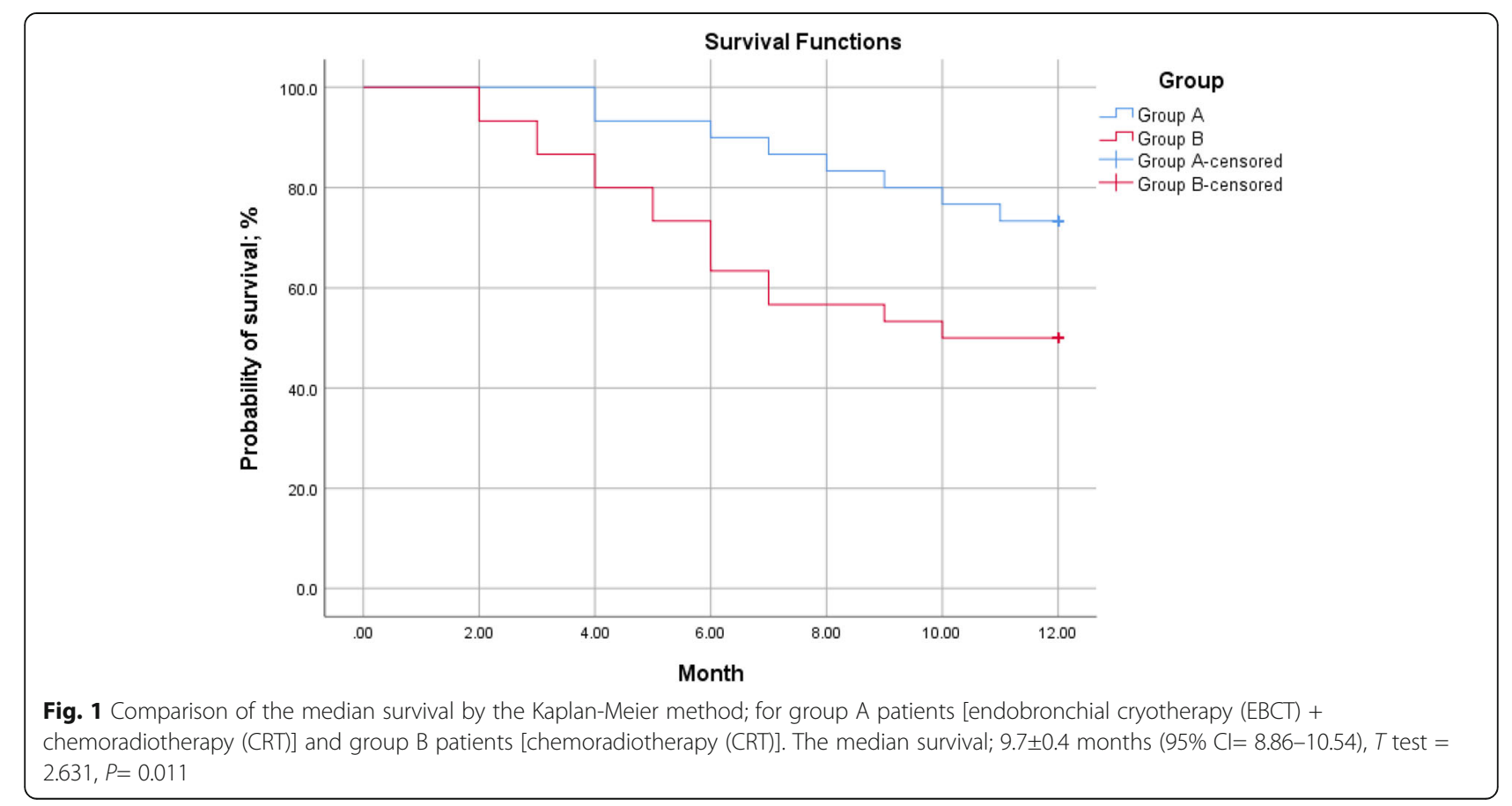




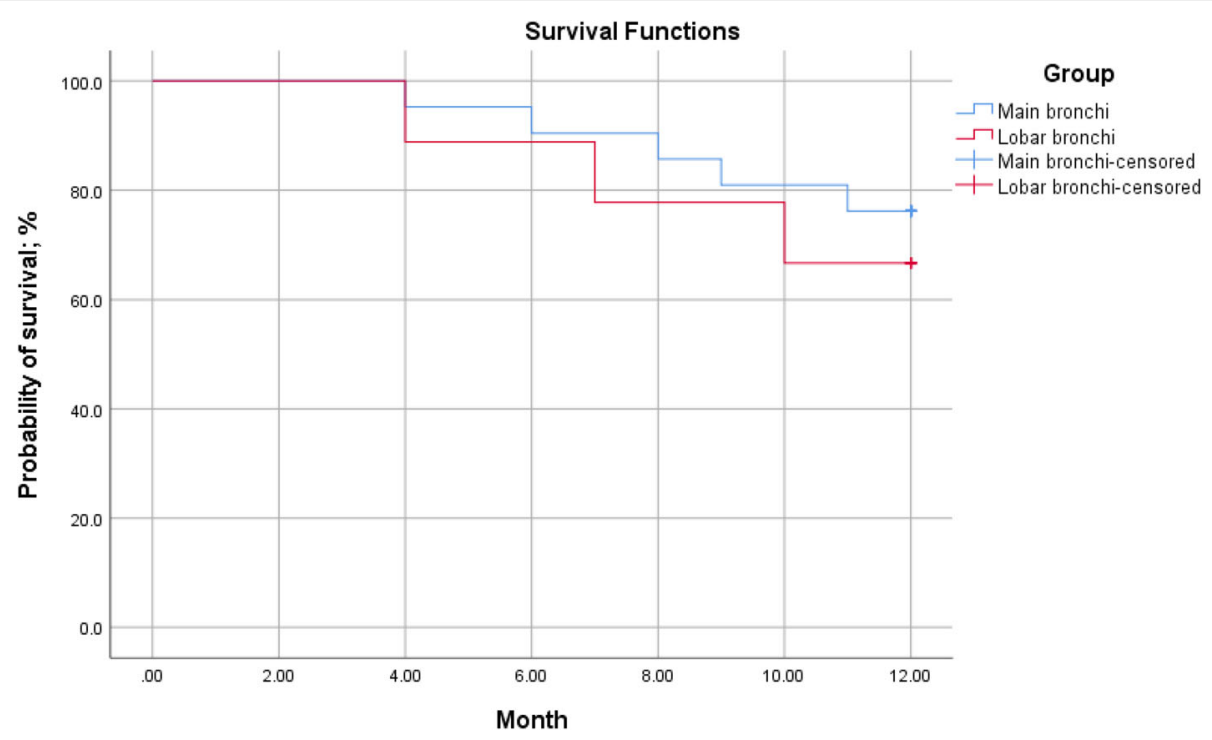

Fig. 2 Comparison of the median survival by the Kaplan-Meier method; for main bronchi patients and lobar bronchi patients in group A patients. The median survival; $10.77 \pm 0.44$ months (95\% $\mathrm{Cl}=9.90-11.63), T$ test $=0.629, P=0.535$

MEBO may cause physical and psychological distress. Cryotherapy was used in the beginning to diagnose MEBO; however, the therapeutic role of cryotherapy and its impact on survival has not been well addressed [14]. In this prospective study, we found that EBCT with CRT improves the symptoms, RFT, ABG, performance status, and median survival in patients with inoperable NSCLC with MEBO.

EBCT was performed successfully in all of our cases. It was effective in relieving cough and dyspnea in all group A cases. Interestingly, hemoptysis was the most distressing complaint, and it was successfully controlled in all group A cases. However, a non-significant improvement in chest pain at 4 weeks follow-up. Similarly, Asimakopoulos et al. reported that EBCT significantly improved the symptoms of dyspnea, cough, and hemoptysis in 329 patients $(P<0.001)[15]$.

Moreover, Maiwand et al. reported that EBCT provided an improvement in hemoptysis (76.4\%), cough (69\%), and dyspnea (59.25\%), in their study including 512 patients with MEBO [16]. Additionally, relief of symptoms in $86 \%$ of cases was reported in a study by Fang et al. [17]. In accordance with previous studies, the symptoms improved post-EBCT in bronchogenic carcinoma patients with MEBO [18-20]. On the contrary, the improvement of the symptoms was seen in $37 \%$ of cases in a study by Walsh et al. [21]. The relatively higher rate of dyspnea improvement could be explained by that we do not have many chronic obstructive pulmonary diseases (COPD) cases, and their mean age was lower than other studies.

During this study, EBCT modality proved itself as an efficient procedure in achieving a significant improvement in the RFT, 6MWD test and the mean ABG parameters in group A compared to group B at 4 weeks follow-up post-therapy. In accordance, there was a significant improvement in FEV1 and FVC post-EBCT in a study by Maiwand et al. (FEV1 from $1.80 \pm 0.6 \mathrm{l}$ to $1.95 \pm 0.8(8.3 \%) \mathrm{l} ; \mathrm{FVC}$ from $2.50 \pm 0.8$ to $2.68 \pm 0.81$ $(7.2 \%)(P<0.05)$ [16]. Similarly, Mohamed et al. reported a significant improvement in mean FVC and mean FEV1 from 1.43 and 1.21 at baseline to 2.41 and 2.94 6 weeks post-EBCT, respectively [19]. Also, Asimakopoulos et al. found that the RFT improved significantly post-EBCT [15]. Oppositely, there was a low percentage of RFT improvement in $24 \%$ of cases in a study by Walsh et al. This could be clarified by that most of their patients were generally old (mean value of age $71 \pm 9.3$ years) with severe limitation of breath and many had the preexisting COPD (82\%) [21].

In our study, the mean Karnofsky performance score showed a significant improvement post-EBCT compared to the baseline score as well compared to group B cases post therapy at follow-up. On the contrary, group B cases showed a non-significant improvement in the performance score compared to the pre-therapy score. In accordance with Fang et al. and Chung F et al., they declared a significant improvement in the performance status post-EBCT in patients with MEBO; furthermore, they were candidates to receive chemotherapy $[17,20]$. Additionally, previous studies reported a similar performance score improvement post cryotherapy $[16,19]$. Nevertheless, Asimakopoulos et al. and Tag-El-din et al. reported a lower incidence of performance score improvement than our results; in $8.5 \%$ and $7 \%$, respectively, $[15,22]$. 
Using the Kaplan-Meier method, the median survival for group A cases was significantly longer than that of group B cases. Our results were comparable with previous studies, which declared that the overall survival was significantly improved in bronchogenic carcinoma patients with MEBO for whom EBCT was done in conjunction with systemic treatment, and it was longer than those who did not receive EBCT $[17,20,23]$. Beeson on here study on 645 patients and about $72 \%$ of them with advanced bronchogenic carcinoma; she declared that cryotherapy could increase the survival rate [24]. Moreover, Asimakopoulos et al. reported that EBCT improved overall survival in patients with advanced lung cancer; also, when performed more than twice (15 months) was better than one session (8.3 months) [15]. Also, Maiwand et al. performed two sessions of cryotherapy for 521 inoperable bronchogenic carcinoma patients and improved survival [16]. Oppositely, Zoganas et al. in their study on inoperable cancer patients and found a non-significant difference in the survival rate over 2 years between the EBCT group compared to anticancer treatment [25]. Limitations of our study include nonrandomization, small sample size, and a short follow-up period.

\section{Conclusion}

The use of EBCT with CRT for the management of MEBO in symptomatic patients with inoperable NSCLC is an efficient and safe procedure. EBCT improves clinical outcomes, RFT, performance status, and median survival.

\section{Abbreviations}

NSCLC: Non-small cell lung cancer; MEBO: Malignant endobronchia obstruction; CRT: Chemoradiotherapy; EBCT: Endobronchial cryotherapy; MRC: Medical Research Council; 6 MWD: Six-minute walking distance; FEV1: Forced expiratory volume in $1 \mathrm{~s}$; FVC: Forced vital capacity; RFT: Respiratory function tests; ABG: Arterial blood gases; COPD: Chronic obstructive pulmonary disease

\section{Acknowledgements}

To the patients who were entrolled in our study and returned back to our hospital for follow-up.

\section{Authors' contributions}

AR: Conceptualization, methodology, writing - review \& editing. MB: Investigation, supervision. MMA: Data curation, writing - original draft. HM: Software, validation, investigation, resources. MA: Writing - review \& editing, visualization, project administration. The authors have read and approved the final manuscript.

\section{Funding}

This research did not receive a grant from any funding agency in the public or commercial sectors.

\section{Availability of data and materials}

The datasets used during the current study are available from the corresponding author on reasonable request.

\section{Declarations}

\section{Ethics approval and consent to participate}

The study conformed to the ethical standards of the Helsinki Declaration, and approval was obtained from the institutional ethics committee of Qena Faculty of Medicine (no. 84), South Valley University (10/12/2016). A written consent was obtained from the study participants.

\section{Consent for publication}

Not applicable.

\section{Competing interests}

The authors declare no competing interests.

\section{Author details}

'Department of Chest Diseases and Tuberculosis, Qena Faculty of Medicine, South Valley University, Qena, Egypt. ²Department of Chest Diseases and Tuberculosis, Luxor Faculty of Medicine, Luxor University, Luxor, Egypt. ${ }^{3}$ Department of Oncology, Qena Faculty of Medicine, South Valley University, Qena, Egypt. ${ }^{4}$ Department of Cardiothoracic Surgery, Qena Faculty of Medicine, South Valley University, Qena, Egypt.

Received: 2 February 2021 Accepted: 10 March 2021

Published online: 26 March 2021

References

1. Torre LA, Bray F, Siegel RL, Ferlay J, Lortet-Tieulent J, Jemal A (2015) Global cancer statistics, 2012. CA Cancer J Clin. 65(2):87-108. https://doi.org/1 $0.3322 /$ caac. 21262

2. Hung MS, Wu YF, Chen YC (2019) Efficacy of chemoradiotherapy versus radiation alone in patients with inoperable locally advanced non-small-cell lung cancer: a meta-analysis and systematic review. Medicine 98(27):e16167

3. Mallow C, Hayes M, Semaan R, Smith T, Hales R, Brower R, Yarmus L (2018) Minimally invasive palliative interventions in advanced lung cancer. Expert Rev Respir Med. 12(7):605-614. https://doi.org/10.1080/17476348.2018.14 86709

4. Noppen M (2002) Interventional palliative treatment options for lung cancer. Ann Oncol 13(4):247-250. https://doi.org/10.1093/annonc/mdf666

5. Ost DE, Ernst A, Grosu HB, Lei X, Diaz-Mendoza J, Slade M, Gildea TR, Machuzak MS, Jimenez CA, Toth J, Kovitz KL, Ray C, Greenhill S, Casal RF, Almeida FA, Wahidi MM, Eapen GA, Feller-Kopman D, Morice RC, Benzaquen S, Tremblay A, Simoff M, AQuIRE Bronchoscopy Registry (2015) Therapeutic bronchoscopy for malignant central airway obstruction: success rates and impact on dyspnea and quality of life. Chest. 147(5):1282-1298. https://doi.org/10.1378/chest.14-1526

6. Mohan A, Harris K, Bowling MR, Brown C, Hohenforst-Schmidt W (2018) Therapeutic bronchoscopy in the era of genotype directed lung cancer management. J Thorac Dis 10(11):6298-6309. https://doi.org/10.21037/jtd.2 018.08.14

7. Wu Y-L, Planchard D, Lu S, Sun H, Yamamoto N, Kim D-W, Tan DSW, Yang JC-H, Azrif M, Mitsudomi T, Park K, Soo RA, Chang JWC, Alip A, Peters S, Douillard JY (2019) Pan-Asian adapted Clinical Practice Guidelines for the management of patients with metastatic non-small-cell lung cancer: a CSCO-ESMO initiative endorsed by JSMO, KSMO, MOS, SSO and TOS. Ann Oncol 30(2):171-210. https://doi.org/10.1093/annonc/mdy554

8. NCCN Clinical Practice Guidelines in Oncology. Non-Small Cell Lung Cancer. Version 3.2020.

9. Ridge CA, Solomon SB, Thornton RH (2014) Thermal ablation of stage i nonsmall cell lung carcinoma. Semin Intervent Radiol 31(02):118-124. https:// doi.org/10.1055/s-0034-1373786

10. Vergnon JM, Huber RM, Moghissi K (2006) Place of cryotherapy, brachytherapy and photodynamic therapy in therapeutic bronchoscopy of lung cancers. Eur Respir J 28(1):200-218. https://doi.org/10.1183/09031936. 06.00014006

11. Niu L, Xu K, Mu F (2012) Cryosurgery for lung cancer. J Thorac Dis 4(4):408419. https://doi.org/10.3978/j.issn.2072-1439.2012.07.13

12. Baust JG, Gage AA, Clarke D, Baust JM, Van Buskirk R (2004) Cryosurgery--a putative approach to molecular-based optimization. Cryobiology. 48(2):190204. https://doi.org/10.1016/j.cryobiol.2004.01.005

13. Maiwand MO (1986) Cryotherapy for advanced carcinoma of the trachea and bronchi. BMJ 293(6540):181-182. https://doi.org/10.1136/bmj.293.6540.181 
14. Nishida H, Yamamoto N, Tanzawa Y, Tsuchiya H (2011) Cryo-immunology for malignant bone and soft-tissue tumors. Int J Clin Oncol 16(2):109-111. https://doi.org/10.1007/s10147-011-0218-2

15. Asimakopoulos G, Beeson J, Evans J, Maiwand MO (2005) Cryosurgery for malignant endobronchial tumors: analysis of outcome. Chest 127(6):20072014. https://doi.org/10.1378/chest.127.6.2007

16. Maiwand MO, Asimakopoulos G (2004) Cryosurgery for lung cancer: clinical results and technical aspects. Technol Cancer Res Treat. 3(2):143-150. https://doi.org/10.1177/153303460400300207 [PubMed: 15059020]

17. Fang YF, Hsieh MH, Wang TY, Lin HC, Yu CT, Chou CL, Lin SM, Kuo CH, Chung FT (2014) Removal of endobronchial malignant mass by cryotherapy improved performance status to receive chemotherapy. Sci World J. 2014: 369739-369736. https://doi.org/10.1155/2014/369739

18. Lee SH, Choi WJ, Sung SW, Kim YK, Kim CH, Zo JI, Park KJ (2011) Endoscopic cryotherapy of lung and bronchial tumors: a systematic review. Korean J Intern Med. 26(2):137-144. https://doi.org/10.3904/kjim.2011.26.2.137

19. Mohamed AS, Alm El-Din MA (2016) Fiberoptic bronchoscopic cryo-ablation of central bronchial lung cancer. Egypt J Chest Dis Tuberc. 65(2):527-530. https://doi.org/10.1016/j.ejcdt.2015.12.016

20. Chung F, Chou C, Lo Y, Kuo C, Wang T, Wang C, Huang H, Lin H, Chang C, Lee $C$, Chen H, Lin S (2019) Factors affecting survival in patients with endobronchial malignant mass after flexible Bronchoscopic cryotherapy: a cohort study. BMC Pulm Med 19:101. https://doi.org/10.1186/s12890-0190854-2

21. Walsh DA, Maiwand MO, Nath AR, Lockwood P, Lloyd MH, Saab M (1990) Bronchoscopic cryotherapy for advanced bronchial carcinoma. Thorax 45(7): 509-513. https://doi.org/10.1136/thx.45.7.509

22. Tag-El-din M, Ashmawi S, Abd El-sabour M et al (2004) Fiberoptic bronchoscopic cryotherapy in the management of tracheobronchial obstruction. Egypt J Chest Dis and Tuberc 53(2):200-208

23. Yuanying $Y$, Lizhi $N$, Feng $M$, Xiaohua $W$, Jianying Z, Fei Y, Feng J, Lihua $H$, Jibing C, Jialiang L, Kecheng X (2013) Therapeutic outcomes of combining cryotherapy, chemotherapy and DC-CIK immunotherapy in the treatment of metastatic non-small cell lung cancer. Cryobiology 67(2):235-240. https:// doi.org/10.1016/j.cryobiol.2013.08.001

24. Beeson J (2007) Palliation of tracheobronchial carcinoma: the role of cryosurgery. J Perioper Pract 17:332, 334-332, 336 338-339

25. Zoganas L, Bablekos G, Maiwand M, Charalabopoulos A, Andronadi V, Batistatou A, Vergoulas G, Charalabopoulos K (2006) Quality of life survey and palliative care in lung cancer patients. Hippokratia 10(4):163-166

\section{Publisher's Note}

Springer Nature remains neutral with regard to jurisdictional claims in published maps and institutional affiliations.

\section{Submit your manuscript to a SpringerOpen ${ }^{\circ}$ journal and benefit from:}

- Convenient online submission

- Rigorous peer review

- Open access: articles freely available online

- High visibility within the field

- Retaining the copyright to your article

Submit your next manuscript at $\boldsymbol{\nabla}$ springeropen.com 